\title{
The Effects of Livestock on California Ground Squirrels (Spermophilus beecheyii)
}

\author{
Jeffrey S. Fehmi, ${ }^{1}$ Sabrina E. Russo, ${ }^{2}$ and James W. Bartolome ${ }^{3}$ \\ Authors are ${ }^{1}$ Research Ecologist, US Army Engineer Research and Development Center, Construction Engineering Research \\ Laboratory, Military Lands Program, 2902 Newmark Drive, Champaign, IL 61821; \\ ${ }^{2}$ Postdoctoral Fellow, Center for Tropical Forest Science-Arnold Arboretum Asia Program, \\ Harvard University, 22 Divinity Ave, Cambridge, MA 02138; and ${ }^{3}$ Professor, Division of Ecosystem Sciences, \\ Department of Environmental Science, Policy, and Management, University of California, \\ 151 Hilgard Hall, Berkeley, CA 95723-3110.
}

\begin{abstract}
Understanding the impacts of livestock grazing on wildlands is important for making appropriate ecosystem management decisions. Using livestock exclosures, we examined the effects of moderate cattle grazing on the abundance of California ground squirrels (Spermophilus beecheyii Richardson) and the spatial distribution of active burrows within their colonies in grassland and blue oak (Quercus douglasii Hook. \& Arn.) savanna habitats in the coastal range of California over a 3-year period (19911994). Overall, relative population densities of California ground squirrels declined significantly throughout the experiment, but did not differ between grazed and ungrazed colonies or between habitats. There was also no significant interaction between these 2 factors. The spatial distribution of burrows, as measured by the mean nearest neighbor distance of active entrances within a colony, did not differ significantly between grazed and ungrazed colonies or between habitats, nor was the interaction significant. Thus, low to moderate levels of cattle grazing did not appear to have a strong effect on the population dynamics of California ground squirrels, and grazing may be compatible with maintenance of ground squirrel populations. Based on multivariate analysis of variance of 1994 data, live plant cover, native plant cover, and standing biomass were lower where the number of burrows was higher on grazed colonies but were little affected on ungrazed colonies. Ground squirrels may increase the impact of livestock grazing and thus reduce the capacity of the land to support other activities. However, it is clear that the effects of livestock grazing are complex and that detailed studies of potential mechanisms by which grazing impacts California ground squirrel populations are necessary.
\end{abstract}

\begin{abstract}
Resumen
Entender el impacto del apacentamiento del ganado en tierras silvestres es importante para tomar decisiones apropiadas sobre el manejo de los ecosistemas. Durante un periodo de tres años (1991-1994) y usando exclusiones de ganado, examinamos los efectos del apacentamiento moderado en la abundancia de ardillas terrestres de California (Spermophilus beecheyii) y la distribución espacial de madrigueras activas dentro de sus colonias en hábitats de pastizal y "Blue oak" (Quercus douglasii) en la región costera de California, USA. En general, las densidades relativaas de la población de ardillas declinó significativamente durante el experimento, pero no hubo diferencia entre colonias con apacentamiento pastoreo y sin apacentamiento, ni entre habitats. Tampoco hubo interacción significativa entre estos dos factores. La distribución espacial de madrigueras, medida por la distancia promedio del vecino más cercano de entradas activas dentro de una colonia, no difirio significativamente entre las colonias apacentadas y no apacentadas ni entre habitats, ni la interacción fue significativa. Así, niveles de apacentamiento bajos a moderados no parecieron tener un efecto fuerte sobre las dinámicas de la población de ardillas, y el apacentamiento puede ser compatible con el mantenimiento de poblaciones de ardillas. Basado en el análisis de varianza múltiple de datos de 1994, la cobertura de plantas vivas, cobertura de plantas nativas, y la biomasa en pie, fueron menores donde el número de madrigueras era mayor en colonias con apacentamiento, pero fueron pocos afectadas en colonias sin pastoreo. Las ardillas terrestres de California pueden aumentar el impacto del apacentamiento del ganado y por consiguiente reducir la capacidad de la tierra para sostener otras actividades. Sin embargo, es claro que los efectos del apacentamiento del ganado son complejos y que son necesarios estudios detallados sobre los mecanismos potenciales por los cuales el apacentamiento impacta las poblaciones de ardillas terrestres de California.
\end{abstract}

Key Words: cattle grazing, California grasslands, oak savanna, burrow patterns

\section{INTRODUCTION}

Livestock use (grazing) of wildlands can have many ecological effects (reviewed in Fleischner 1994, Milchunas et al. 1998), including demographic effects on plant and animal species, alteration of the structure of ecological communities, and alteration of ecosystem structure and function. Understanding the effects of grazing at the population, community, and

\footnotetext{
We are grateful to the East Bay Regional Park District and the US Army Corps of Engineers, Construction Engineering Research Laboratory for support.

Correspondence: James W. Bartolome, Division of Ecosystem Sciences, ESPM Department, University of California, 151 Hilgard Hall, Berkeley, CA 95723-3110. Email: jwbart@nature.berkeley.edu
}

Manuscript received 11 March 2003; manuscript accepted 20 January 2005. 
ecosystem levels is critical for making appropriate management decisions (Fleischner 1994). The impacts caused by grazing on a particular ecological system, however, depend upon many factors, such as evolution of the system in the presence of large mammalian herbivores (Mack and Thompson 1982; Milchunas et al. 1988; Bock and Bock 1993), habitat type and its ecological condition (Proulx and Mazumder 1998; Hatch et al. 1999), climate (Milchunas et al. 1988), taxa under study (Bock et al. 1984; Milchunas et al. 1998), and seasonal timing and intensity of grazing (Menke 1992).

Substantial variation in the responses of both native plant and animal communities to grazing has been documented (Daubenmire 1940; White 1967; Rickard et al. 1975; Szaro and Pase 1983; Bock and Bock 1993; Noy-Meir 1995; Schuman et al. 1999; Stohlgren et al. 1999). One consistent finding for both plants and animals, however, is that responses to grazing are often species-specific, even within ecological guilds and taxonomic groups. For example, species-specific responses by native grasses and forbs to fire disturbance and cessation of grazing complicate efforts to restore grasslands in California (Hatch et al. 1999). The cumulative effects of livestock grazing on an ecological community are a composite of several different individual effects, such as herbivory, trampling, and elimination. It is therefore reasonable to expect variation in the effects of grazing on any particular plant or animal species.

The effects of grazing on small mammal species populations can be variable. Kangaroo rats (Dipodomys sp.; Rodentia) have been found at higher population densities in grazed compared with ungrazed areas (Reynolds and Trost 1980; Bock et al. 1984; Jones and Longland 1999), whereas population densities of other small mammal species are lower in grazed areas (Reynolds and Trost 1980; Bock et al. 1984; Medin and Clary 1989; Hayward et al. 1997, Jones and Longland 1999) or appear unaffected (Heske and Campbell 1991). Some small mammal species, however, are only found in areas protected from grazing (Medin and Clary 1989). Such species-specific responses to grazing typically result in altered structure of animal assemblages in grazed relative to ungrazed areas (Milchunas et al. 1998; Jones 2000). Some differences among animal species in their responses to grazing may be mediated by interactions between the direct effects of grazing on habitat quality and speciesspecific habitat requirements (Hayward et al. 1997; Germano et al. 2001). For example, grazing may induce changes in habitat structure that affect foraging efficiency or thermoregulation (Jones 1981; Bock et al. 1984) or the detection and avoidance of predators (Hayward et al. 1997; Germano et al. 2001) or cause competition with livestock for forage (Reynolds and Trost 1980). However, for conservation, the interaction between livestock grazing and small mammals may be most detectable in the plant community where their activities most overlap.

Using livestock exclosures, we examined the effects of moderate cattle grazing on the abundance of California ground squirrels (Spermophilus beecheyii Richardson) and the spatial distribution of active burrows within their colonies in grassland and blue oak (Quercus douglasii Hook. \& Arn.) savanna habitats in the coastal range of California during a 3-year experiment. Because livestock grazing has the potential to change both resource availability and ground squirrels' ability to detect predators, we did not hypothesize a priori that an increase or decrease in squirrel abundance or specific change in spatial pattern of active burrows would result from grazing. Our null hypothesis was that ground squirrel numbers and spatial placement of burrows would not differ in grazed and ungrazed colonies in grasslands and oak savannas. We also hypothesized that the combination of livestock grazing and squirrel activity would have no impact on the proportion of native plant cover on the colonies.

\section{MATERIALS AND METHODS}

\section{Natural History and Study Location}

The California ground squirrel is a native colonial rodent common in grasslands and savannas in western North America (Ingles 1965). California ground squirrels principally eat seeds (especially of grasses and oaks), new growth of grass, and fruits, and supplement their diet to an unknown degree with insects (e.g., grasshoppers) and grass roots (Linsdale 1946). California ground squirrels are thought to compete with livestock for forage (Storer 1942), but the ecological impact of any such competition has not been quantified.

Avoidance of predation is an important component of the California ground squirrel's social system. California ground squirrels employ a system of vocalizations and postures to signal alarm and avoid predation (Linsdale 1946; Hennessy et al. 1981; Hersek and Owings 1994; Swaisgood et al. 1999). Predators of California ground squirrels include rattlesnakes (Crotalus viridis Rafinesque; Swaisgood et al. 1999); raptors, including Redtailed Hawks (Buteo jaimacensis Gmelin), Golden Eagles (Aquila chrysaetos Linnaeus), and Prairie Falcons (Falco mexicanus Schlegel; Ogden and Hornocker 1977; Steenhof and Kochert 1988); coyotes (Canis latrans Say); foxes (Vulpes vulpes Linnaeus); and bobcats (Lynx rufus Schreber; Linsdale 1946), all of which maintain breeding or wintering populations in the region in which the study site is located.

East Bay Regional Park District's Del Valle Park (lat $37^{\circ} 35^{\prime} 47^{\prime \prime} \mathrm{N}$, long $121^{\circ} 42^{\prime} 47^{\prime \prime} \mathrm{W}$; elevation $305 \mathrm{~m}$ ) in the coastal range of California is a mosaic of grasslands and oak savannas (Bartolome 1987), and California ground squirrels are abundant in both habitats. The historical herbaceous composition is unknown (Hamilton 1997); however, the native vegetation was likely dominated by perennial bunchgrasses with native annual grasses and forbs occupying the interspaces (Heady et al. 1992). At Del Valle Park, common herbaceous vegetation includes the nonnative grasses Avena barbata Link, Bromus madritensis L., Bromus hordeaceus L., and Bromus diandrus Roth; forbs include Brassica nigra (L.) Koch and Carduus pycnocephalus L. Native vegetation on the site includes Achillea millefolium L., Ceanothus megacarpus Nutt., Clarkia sp., Epilobium sp., Hemizonia congesta DC., Melica californica Scribner, Nassella pulchra (A. Hitch.) Barkworth, Plagiobothrys nothofulvus A. Gray, and Sisyrinchium bellum S. Watson in addition to blue oak trees (Quercus donglasii).

Livestock grazing has occurred in California since 1769, with the arrival of the Spaniards (Burcham 1956). The Del Valle area has been grazed year-round by cattle since about 1800, but had not been grazed for 3 years before this study because of an extended drought. Livestock grazing was reintroduced to the park in early 1991 under the park's grazing management plan which permits livestock grazing while herbaceous vegetation 
remains above $1200 \mathrm{~kg} \cdot \mathrm{ha}^{-1}$. Livestock typically begin grazing the park in March or April and are removed in early- to midsummer when approximately $1200 \mathrm{~kg} \cdot \mathrm{ha}^{-1}$ average residual dry matter (RDM) remains. This level of livestock use is considered low to moderate for this region (Harris et al. 2002) and conserves the plants, soils, and water of the park.

\section{Field Methods}

We selected 3 sites within the southeastern portion of the park according to the following criteria: 1 ) vegetation consisted of annual grassland or of blue-oak-dominated savanna (approximately $50 \%$ tree canopy coverage), 2) at least 12 active squirrel colonies were within a contiguous 4-ha area, 3) slope was less than $40 \%$, and 4 ) the area was commonly used by livestock. Each site's grassland and savanna habitats were separated on a map into 2 grassland and 2 savanna areas, which were then randomly assigned to either grazed or ungrazed treatments. Fencing to exclude cattle was constructed in fall 1991. Thus, each of the 3 sites included 4 experimental units: grazed and ungrazed grassland and grazed and ungrazed oak savanna.

Within each experimental unit, 3 active squirrel colonies were randomly selected and marked with steel rebar at the center of colony activity. To be considered for selection, colonies had to be more than $15 \mathrm{~m}$ from the exclosure boundaries, have at least 30 $\mathrm{m}$ separating them from the next nearest colony, and have at least 5 burrow entrances ( 12 colonies had 5-9 entrances, 10 had 10-18 entrances, and 14 had 21-42 entrances). A total of 36 colonies were in the study, with 9 colonies in each of the 4 treatment combinations. All burrow entrances within a $10-\mathrm{m}$ radius of the colony center were mapped (Fig. 1) and rated for activity in annual censuses every fall from 1991 through 1994. The colony census in 1991 occurred before the grazing treatment had been applied and thus represented the initial conditions at the site. Each burrow entrance was rated from 0 to 4 to categorize colony activity: " 0 " indicated no evidence of a previously mapped entrance; " 1 " indicated an entrance filled with dirt, with vegetation growing on filled surfaces, and with no other paths to other burrow entrances evident; " 2 " indicated an entrance filled or partially filled with no evidence of recent use or soil disturbance, but with vegetation not yet reestablished on the fill; " 3 " indicated an open entrance with no evidence of recent use or soil disturbance, with debris or spider webs in the opening, but with evidence of paths to other burrow entrances; "4" indicated an open entrance with evidence of recent use in terms of soil disturbance and active use of paths to other entrances. Active burrow entrances were those with a rating of 3 or 4 . Observing the number and location of active burrow entrances per colony is a commonly employed technique for censusing ground squirrels. The number of active burrow entrances has been shown to be predictive of ground squirrel population densities (Owings and Borchert 1975; Nydegger and Smith 1986), although this technique may have variable predictive power (Van Horne et al. 1997).

Herbaceous vegetation at each colony was evaluated to determine livestock use and assess site quality in terms of herbaceous cover and primary productivity. At the end of each growing season from 1992-1994, all aboveground herbaceous vegetation was clipped and collected from a plot of $625 \mathrm{~cm}^{2}$ in area randomly located near the center of each of the 36 colonies.

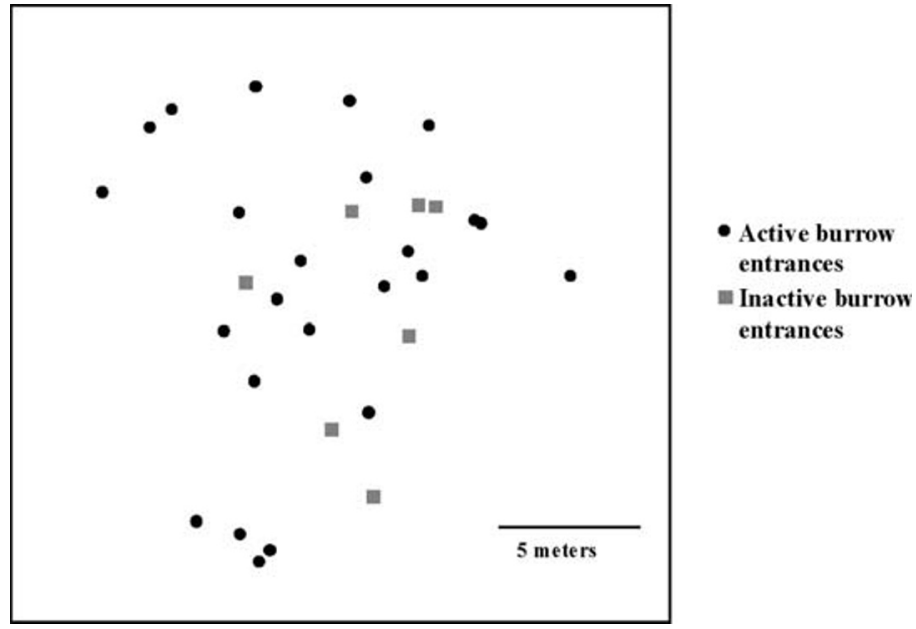

Figure 1. A representative California ground squirrel colony showing locations of active (black dots) and inactive (gray squares) burrows in 1991.

For each of the 18 grazed colonies, an additional $625-\mathrm{cm}^{2}$ plot was covered by a cage $\left(1 \mathrm{~m}^{3}\right)$ made of hardware cloth $(5 \times 10$ $\mathrm{cm}$ mesh size), which prevented grazing by livestock. The clipped vegetation was dried at $65^{\circ} \mathrm{C}$ for 48 hours and weighed. To estimate changes in the vegetative composition, a $25-\mathrm{m}$ transect bisecting each colony was sampled at the end of the growing season on 24-26 May 1994. We recorded plant species for the first hit on a live plant part by a vertically lowered pin every $0.5 \mathrm{~m}$ along the line transect.

\section{Statistical Analyses}

We analyzed the effects of the grazing (grazed or ungrazed) and habitat (grassland or savanna) treatments on the number of active ground squirrel burrow entrances in each colony in each year (1992-1994), relative to the baseline provided by the pretreatment year (1991). The proportional change in numbers of burrow entrances, as an estimate of the relative population density of ground squirrels, was calculated by dividing the number of active burrow entrances per colony in each census year (1992-1994) by the number of active burrow entrances per colony before the grazing treatment was applied in 1991. This method allows better comparison of colonies because it controls for the initial differences in colony sizes.

To investigate the effects of the grazing and habitat treatments on the spatial distribution of active burrow entrances in each colony, we calculated the mean nearest-neighbor distance (NND) of active burrow entrances for each colony (Clark and Evans 1954). The mean NND has been shown to be normally distributed (Donnelly 1978). Therefore, we used the mean NND as the dependent variable in the same models as described above for the burrow entrances. Because the precision of any indicator of spatial relationship, such as NND, is inversely related to sample size, we weighted the dependent variable (mean NND) by the number of burrow entrances in each colony in each year. Analysis of NND allows detection of changes in the distance between squirrel burrows within colonies and provides a measure of behavioral change separate from the relative density of a colony. We tested the effect of the 


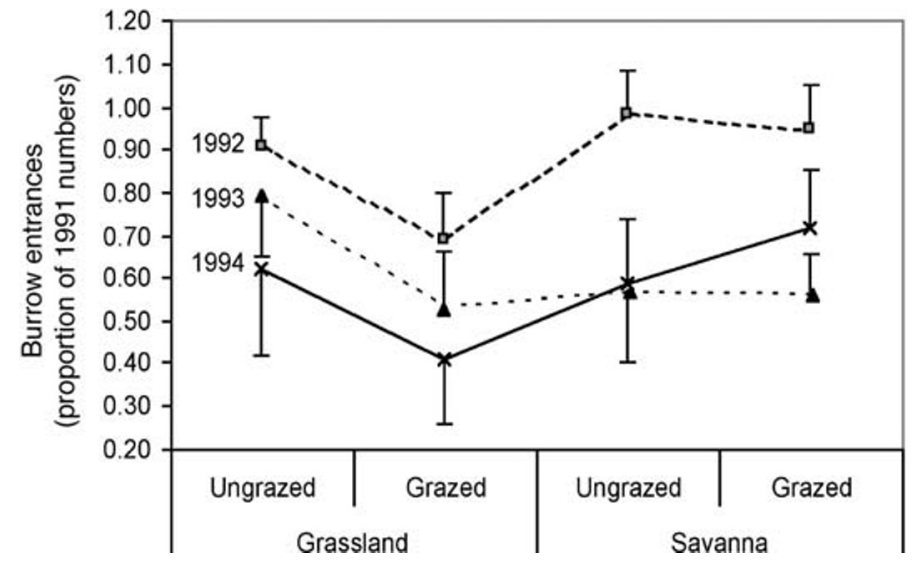

Figure 2. The number of burrow entrances of California ground squirrels by grazing treatment and grassland and savanna habitats as a proportion of 1991 (baseline) numbers. Error bars represent the standard error of the mean.

grazing exclosure by comparing weights of herbaceous vegetation inside and outside of caged vegetation plots in the colonies exposed to grazing.

The mixed procedure in SAS (SAS System 2000) with a repeated measures design accounting for "site" in the model as a block (random effect) was used for all analyses. In each analysis, the full model with all main effects and interactions was tested, and insignificant terms were pooled into error. The final model was the one with the lowest value of Akaike's information criterion (Burnham and Anderson 1998). Degrees of freedom were determined using the Satterthwaite method (Littell et al. 1996). Assumptions of homoscedasticity and sphericity were met, and transformations were used when necessary to achieve normality of the data.

To estimate the effects of the squirrel colonies and the treatments on the plant community, we analyzed the transect data and the uncaged clipping data with a multivariate analysis of variance (MANOVA) using total cover, cover of natives, and the dry weight of standing biomass as the dependent variables in separate analyses. The number of burrow entrances per colony in 1994, the average NND in 1994, the blocking factor, and the grazing and habitat treatments were used as the independent variables. Transformations were used when necessary to achieve normality of the residuals. The analysis of variance procedure is needed to calculate the statistics in the presence of the correlations among the dependent variables and obviate the concerns from the use of multiple independent tests.

\section{RESULTS}

The number of burrow entrances (as a proportion of the 1991 numbers) of California ground squirrels did not differ between grazed and ungrazed colonies $(P=0.23)$ nor between grassland and savanna habitats $(P=0.43)$, and there was no significant interaction between grazing treatment and habitat $(P=0.13)$. Burrow entrance numbers declined significantly throughout the experiment $(P<0.01$; Fig. 2$)$, and the severity of the decline varied significantly between habitats $(P<0.01)$, but inference is weak in estimating year effects in our repeated measures design.

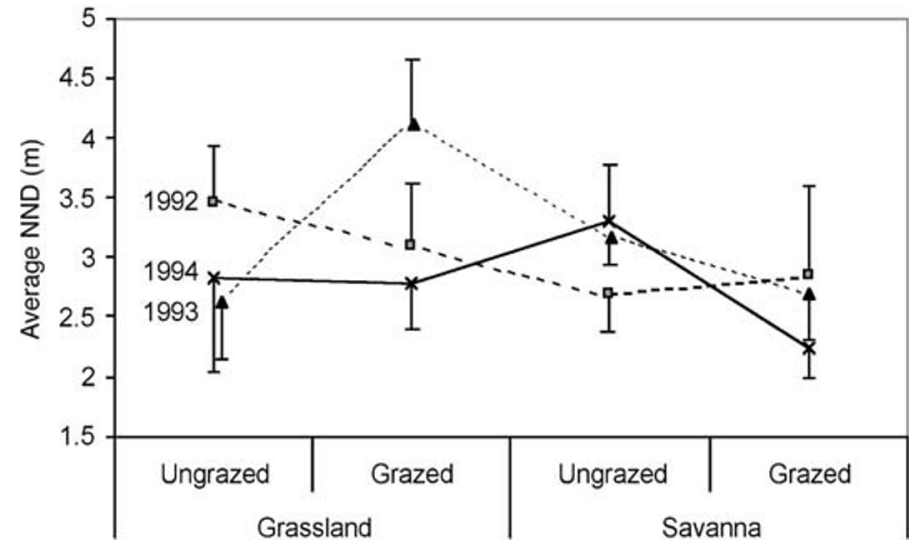

Figure 3. Average nearest neighbor distance (NND) of active burrow entrances in grazed and ungrazed California ground squirrel colonies in grassland and savanna habitats. No differences were significant. Error bars represent the standard error of the mean.

The spatial distribution of burrows as measured by the mean NND of active entrances within a colony did not differ significantly between grazed and ungrazed colonies $(P=0.26)$ or between habitats $(P=0.06)$, nor was the interaction between these factors significant $(P=0.08$; Fig. 3). No other terms in this model were significant.

Based on MANOVA of 1994 data, live plant cover, native plant cover, and standing biomass were lower where the number of burrows was higher on grazed colonies but were little affected on ungrazed colonies (Fig. 4). The number of burrows was a significant effect $(P=0.03)$ but must be considered as part of the significant interaction between the number of burrows and the grazing treatment $(P=0.046$; Fig. 4$)$. Habitat was also significant $(P=0.01)$ but this was substantially because of the effect of standing biomass (see below). Native plant cover (irrespective of oaks) was associated with a significant interaction $(P=0.04$; Fig. 5$)$ between the number of burrow entrances and the distance between them (average NND). Native cover decreased with increasing numbers of burrow entrances and decreasing NND.

In grazed California ground squirrel colonies, dry weight of standing biomass in plots protected from grazing (caged plots) was significantly greater than that in unprotected plots $(55$ $\left.\mathrm{g} \cdot \mathrm{m}^{-2}, P=0.02\right)$. The grazing exclosure treatment therefore appears effective in that herbivory by cattle resulted in a significant decrease in herbaceous vegetation in uncaged relative to caged plots and the average livestock consumption was 550 $\mathrm{kg} \cdot \mathrm{ha}^{-1}$. As expected, herbaceous standing biomass (which did not include oak biomass) was significantly higher in the grassland than in the oak savanna $\left(312 \mathrm{~g} \cdot \mathrm{m}^{-2}\right.$ vs. $130 \mathrm{~g} \cdot \mathrm{m}^{-2}$, $P<0.01)$. These amounts are lower than the true primary production because squirrels had access to cage interiors and because cages generally provide relative rather than absolute estimates of primary production (Parsons et al. 1984).

\section{DISCUSSION}

Our results show no statistically significant direct effects of low to moderate levels of cattle grazing (i.e., RDM levels of 1200 

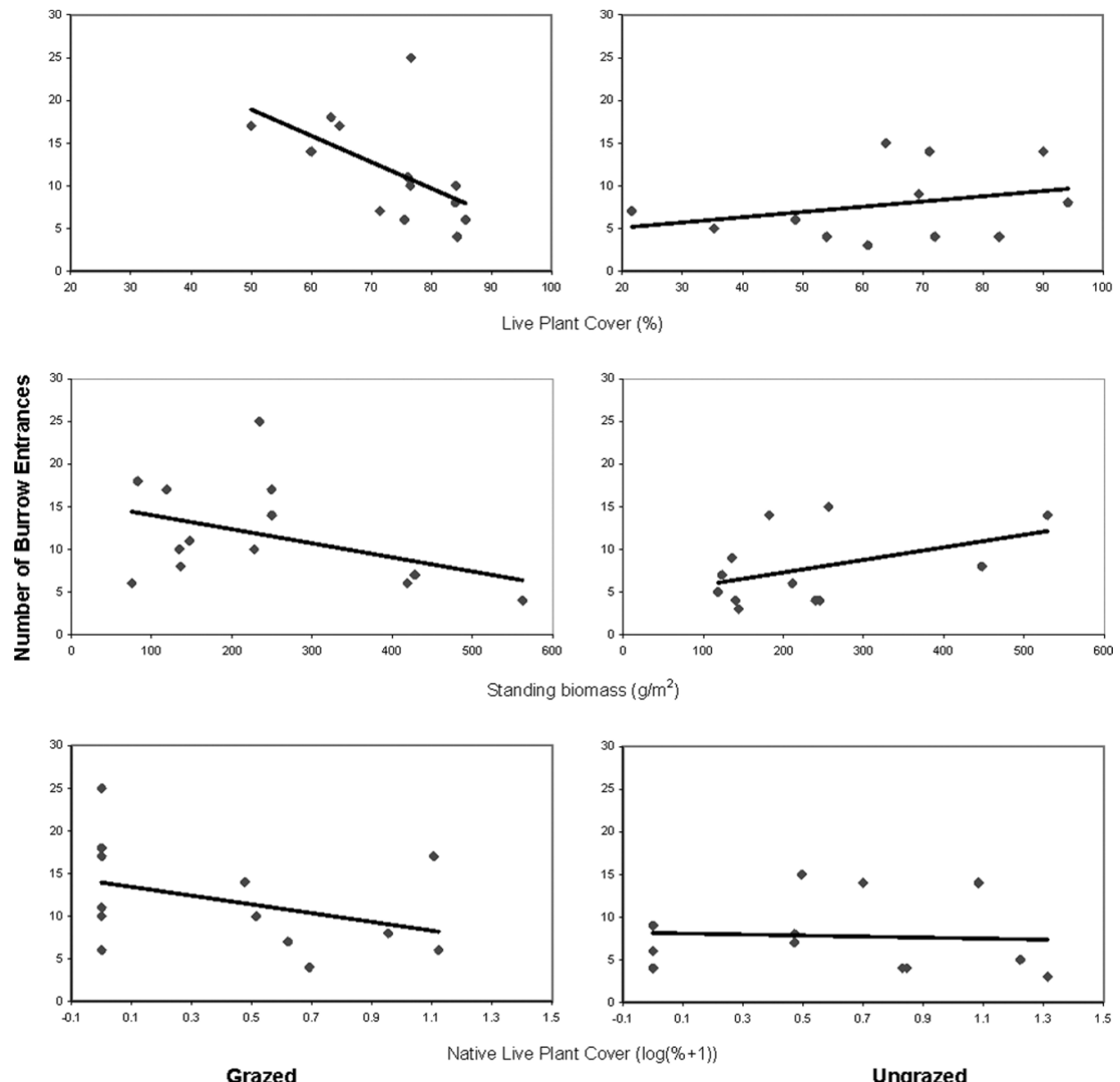

Figure 4. The univariate results of the MANOVA for the 1994 data. Live plant cover, native plant cover, and standing biomass decreased as the number of burrows increased on grazed colonies but were little affected on ungrazed colonies $(P=0.046)$.

$\mathrm{kg} \cdot \mathrm{ha}^{-1}$ ) on either the density or the spatial distribution of active burrow entrances within colonies of California ground squirrels. A power test (following Cohen 1988) indicated that statistical power of the design was large enough to detect relatively weak treatment effects $(F \leq 0.1)$, suggesting that our findings of no direct effects of grazing were not because of lack of replication. Our finding of no direct effects of grazing could result from low grazing intensity. However, this level of grazing was typical for the region. It is therefore of ecological and managerial importance to understand what the impacts of actual grazing pressures may be in a given ecosystem.

Ground squirrels prefer more open habitats (Ingles 1965), and they may abandon their burrows or change the spatial distribution of their entrances if vegetation grows high enough to obscure common predators, as may occur in ungrazed areas. Similar habitat selection has been documented in yellow-bellied marmots (Marmota flaviventris Eschscholtz), which abandon burrows when vegetation grows high enough to provide predator concealment (Svendsen 1976; Carey 1985) and kangaroo rats, which occur at higher densities in grazed compared to ungrazed areas (Jones and Longland 1999). Actual or perceived risk of predation can influence the spatial distribution and habitat selection of animals, and a trade-off exists between avoiding predation and engaging in other activities that may increase fitness (e.g. foraging and mating; Lima and Dill 1990).
Thus, preferences for open habitats vs. habitats with substantial vegetative cover may underlie some differences in the responses of small mammal species to grazing (Bock et al. 1984; Jones and Longland 1999). Such preferences may underlie variation in abundances of other vertebrates in grazed and ungrazed habitats, as well (Jones 1981; Germano et al. 2001).

Grazing may have many effects on a particular species, and some of these effects may counteract each other, as is characteristic of some symbioses involving herbivores (Coppock et al. 1983; Krueger 1986). Any advantages of grazing conferred to squirrels by virtue of increased predator detection from reduced vegetative cover may be counterbalanced by other disadvantages caused by grazing such as competition for forage. Such conflicts could explain why other studies of longer duration than that reported here have found no detectable effects of grazing in other small mammal species (e.g., Roundy and Jordan 1988; Heske and Campbell 1991). Whereas our study did not find increases in densities of California ground squirrels with grazing, other studies have suggested that California ground squirrels may have higher population densities in grazed compared to ungrazed areas. On Hastings Reservation in California, when lands formerly grazed were protected from grazing, the densities of California ground squirrels fell precipitously (Linsdale 1946). Studies at the San Joaquin Experimental Range near Fresno, California, showed similar results in that squirrel populations 


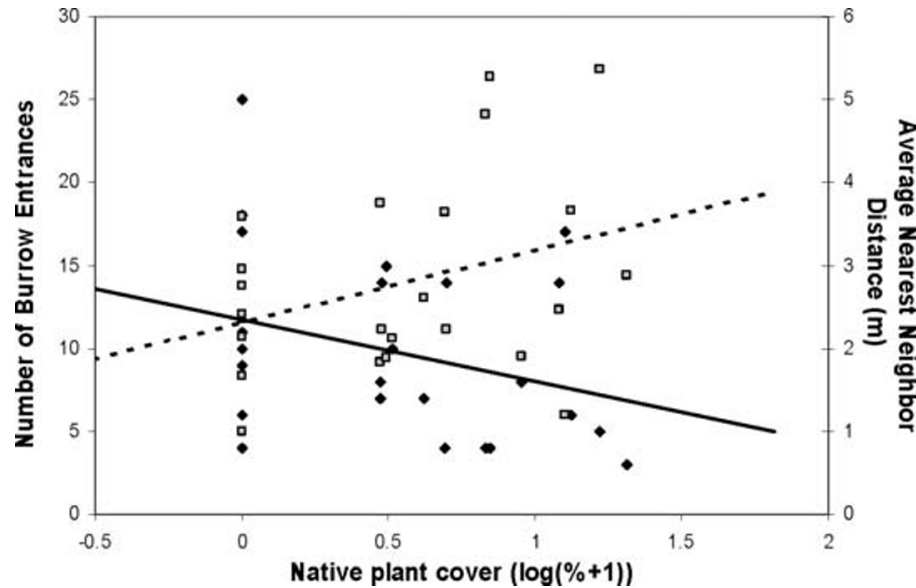

Figure 5. Native plant cover (irrespective of oaks) was associated with a significant interaction $(P=0.04)$ between the number of burrow entrances and the distance between them (average NND).

were larger in areas grazed by livestock compared with ungrazed areas (Howard et al. 1959; Fitch and Bentley 1949). Other studies have documented higher predation risk for ground squirrels in habitats with high, compared to low, vegetative cover (Schooley et al. 1996; Sharpe and Van Horne 1998). Furthermore, the spatial distribution of Arctic ground squirrels (S. parryii plesius Osgood) may be directly linked to predation risk because squirrels tend not to occupy habitats that reduce their ability to perceive predators (Karels and Boonstra 1999).

California ground squirrels are likely to share some food resources with cattle, such as new grass growth. In California, new grass growth may be limiting in the dry season, when most grasses are dormant. During this time, any competition between cattle and California ground squirrels for shared resources may have adverse impacts on the squirrels because cattle have a larger range and a less discriminating diet. We have no direct evidence of what positive or negative effects California ground squirrels may experience in the presence of cattle. Our study demonstrates that, cumulatively, low to moderate levels of grazing appear to have no detectable effect on population densities of California ground squirrels. However, we found evidence that resource availability (in terms of live plant cover, native plant cover, and standing biomass) was negatively related to population densities of California ground squirrels in the presence of cattle grazing.

Decreased live plant cover, native plant cover, and standing biomass associated with increased burrow numbers in the presence of livestock grazing showed the general decline in quantity and forage quality of vegetation as a result of the combination of herbivores (Fig. 4). This effect could be considered as an intensification of the normal effects of livestock grazing, at least within the colony boundary. This end result may cause predicted livestock impacts to be underestimated in areas with substantial squirrel populations, which could be important for many management considerations, including the assessment of erosion potential, the advisability of off-road activities, and the impact on other animals. The univariate analysis of native plant cover (other than the oaks) showed a decrease with increasing number of burrows (Fig. 5) but the decrease was contingent on the distance between the holes. This makes intuitive sense because the squirrels should impact plants less with distributed activities and fewer squirrels.

Although livestock use was readily apparent in the grazed areas, the clipped plots seemed to substantially underestimate the standing biomass for both grazed and ungrazed treatments as well as both the grasslands and savanna habitat types. This most probably was because of the location of the plots within the squirrel colonies, which did not afford us an estimate of standing biomass production independent of squirrels. In addition, the caged plots used to estimate livestock effects allowed squirrel access, and cage interiors possibly provided a predator-free refuge, which may have magnified their use.

The fenced livestock exclosures used to create the ungrazed treatments were large enough to contain the core home ranges of the squirrel colonies ( $\sim 0.28 \mathrm{ha}$; Linsdale 1946$)$ within them, but nothing except distance prevented the squirrels on either side of the fence from using resources outside of their assigned treatment. Although we assumed that adjacent resources predominated, others have occasionally noted squirrels as having traveled more than $1000 \mathrm{~m}$ from their home colony (Linsdale 1946), which, in our experiment, would put them well outside the treated areas. Correctly or incorrectly, conditions within $30 \mathrm{~m}$ of the colony, where more than $60 \%$ of all activity occurs (Lindsdale 1946), were assumed to be the most important when our experiment was designed.

Other mechanisms may also explain our finding of no significant effect of grazing on population densities of ground squirrels. Population dynamics of many small mammals are controlled by predation (e.g., Pitelka et al. 1955). California ground squirrel populations may be more affected by predators such as raptors, coyotes, and foxes than by effects mediated by cattle grazing. Alternatively, ground squirrels may compete for forage more with other herbivorous small mammals than with cattle. Furthermore, competition with cattle, if present, may only be significant in years with limited forage. Management of grazing at Del Valle Park may prevent forage levels from ever reaching this critical threshold. It is clear that the effects of livestock grazing are complex and that detailed studies of potential mechanisms by which grazing impacts populations are necessary.

\section{MANAGEMENT IMPLICATIONS}

Low to moderate levels of cattle grazing did not seem to strongly affect the population dynamics of California ground squirrels, and grazing may be compatible with maintenance of ground squirrel populations. Our experiment provides no direct evidence that livestock grazing should be eliminated to conserve or enhance populations of squirrels or the predator populations that they support. However, we find some limited evidence that California ground squirrels may increase the impact of livestock grazing and thus reduce the capacity of the land to support other activities such as recreation or military training. Future research should include experiments with heavier grazing and more intensive sampling of forage availability as well as measuring plant heights and concealment value. Studies of dietary preferences of ground squirrels would also resolve the extent to which dietary overlap is important in this interaction. 


\section{ACKNOWLEDGMENTS}

We would like to thank E. J. Heske and Peter Hopkinson for comments on an earlier draft and S. Aref and R. J. Melton for statistical guidance.

\section{LITERATURE CITED}

BARTOLOME, J. W. 1987. California annual grassland and oak savannah. Rangelands 9:122-125.

Bock, C. E., AND J. H. Bock. 1993. Cover of perennial grasses in southeastern Arizona in relation to livestock grazing. Conservation Biology 7:371-377.

Bock, C. E., J. H. Bock, W. R. Kenney, and V. M. Hawthorne. 1984. Responses of birds, rodents and vegetation to livestock exclosure in a semidesert grassland site. Journal of Range Management 37:239-242.

Burcham, L. T. 1956. Historical backgrounds of range land use in California. Journal of Range Management 9:81-86.

Burnham, K. P., and D. R. Anderson. 1998. Model selection and inference: A practical information-theoretic approach. New York, NY: Springer. $488 \mathrm{p}$.

CareY, H. V. 1985. The use of foraging areas by yellow-bellied marmots (Marmota flaviventris). Oikos 44:273-279.

Clark, P. J., and F. C. Evans. 1954. Distance to nearest neighbor as a measure of spatial relationships in populations. Ecology 35:445-453.

COHEN, J. 1988. Statistical power analysis for the behavioral sciences. Hillsdale, $\mathrm{NJ}$ : Laurence Erlbaum and Associates. $594 \mathrm{p}$.

Coppock, D. L., J. E. Ellis, J. K. DetLing, and M. I. Dyer. 1983. Plant-herbivore interactions in a North American mixed-grass prairie: 2. responses of bison (Bison bison) to modification of vegetation by prairie dogs (Cynomys ludovicianus). Oecologia 56:10-15.

Daubenmire, R. F. 1940. Plant succession due to overgrazing in the Apropyron bunchgrass prairie of southeastern Washington. Ecology 21:55-64.

DonnelLy, K. P. 1978. Simulations to determine the variance and edge effect of total nearest-neighbor distance. In: I. Hodder [ed.]. Simulation studies in archaeology. Cambridge, UK: Cambridge University Press, p 91-95.

Fitch H. S., AND J. R. BentLEY. 1949. Use of California annual plant forage by range rodents. Ecology 30:306-321.

FleischneR, T. L. 1994. Ecological costs of livestock grazing in western North America. Conservation Biology 8:629-644.

Germano, D. J., G. B. Rathbun, and L. R. Saslaw. 2001. Managing exotic grasses and conserving declining species. Wildlife Society Bulletin 29:551-559.

Hamilton, J. G. 1997. Changing perceptions of pre-European grasslands in California. Madrono 44:311-333.

Harris, N. R., W. E. Frost, N. K. McDougald, M. R. George, and D. L. Nielsen. 2002. Long-term residual dry matter mapping for monitoring California hardwood rangelands. USDA Forest Service General Technical Report PSW-GTR-184. $846 \mathrm{p}$.

Hatch, D. A., J. W. Bartolome, J. S. Fehmi, and D. S. Hillyard. 1999. Effects of burning and grazing on a coastal California grassland. Restoration Ecology 7:376-381.

Hayward, B., E. J. Heske, and C. W. Painter. 1997. Effects of livestock grazing on small mammals at a desert cienega. Journal of Wildllife Management 61: 123-129.

Heady, H. F., J. W. Bartolome, M. D. Pitt, G. D. Savelle, and M. C. Stroud. 1992. California prairie. In: R. T. Coupland [ed.]. Ecosystems of the world. Amsterdam, The Netherlands: Elsevier, p 313-335.

Hennessy, D. F., D. H. Owings, M. P. Rowe, R. G. Coss, and D. W. Leger. 1981. The information afforded by a variable signal: constraints on snake-elicited tail flagging by California, USA, ground squirrels (Spermophilus beecheyI). Behaviour 78:188-226.

Hersek, M. J., and D. H. Owings. 1994. Tail flagging by young California ground squirrels, Spermophilus beecheyi: age-specific participation in a tonic communicative system. Animal Behavior 48:803-811.

Heske, E. J., and M. CampBell. 1991. Effects of an 11-year livestock exclosure on rodent and ant numbers in the Chihuahuan Desert, southeastern Arizona (USA). Southwestern Naturalist 36:89-93.
Howard, W. E., K. A. Wagnon, and J. R. Bentley. 1959. Competition between ground squirrels and cattle for range forage. Journal of Range Management 12: 110-115.

Ingles, L. G. 1965. Mammals of the Pacific States. Palo Alto, CA: Stanford University Press. 506 p.

Jones, A. 2000. Effects of cattle grazing on North American arid ecosystems: a quantitative review. Western North American Naturalist 60:155-164.

Jones, A. L., AND W. S. Longland. 1999. Effects of cattle grazing on salt desert rodent communities. American Midland Naturalist 141:1-11.

JoNES, K. B. 1981. Effects of grazing on lizard abundance and diversity in western Arizona, USA. Southwestern Naturalist 26:107-116.

Karels, T. J., and R. Boonstra. 1999. The impact of predation on burrow use by Arctic ground squirrels in the boreal forest. Proceedings of the Royal Society of London 266:2117-2123.

KRUEGER, K. 1986. Feeding relationships among bison (Bison bison), pronghorn (Antilocapra americana) and prairie dogs (Cynomys Iudovicianus): an experimental analysis. Ecology 67:760-770.

LiMA, S. L., AND L. M. DiLL. 1990. Behavioral decisions made under the risk of predation. Canadian Journal of Zoology 68:619-640.

LinSDALE, J. M. 1946. The California ground squirrel. Berkeley, CA: University of California Press. $476 p$

Littell, R. C., G. A. Milliken, W. W. Stroup, and R. D. Wolfinger. 1996. SAS system for mixed models. Cary, NC: The SAS Institute, Inc. 633 p.

Mack, R. N., AND J. N. Thompson. 1982. Evolution in steppe with few large, hooved mammals. American Naturalist 119:757-773.

Medin, D. E., and W. P. Clary. 1989. Small mammal populations in a grazed and ungrazed riparian habitat in Nevada. USDA Forest Service Research Paper INT-413: 5 p.

MenKE, J. W. 1992. Management controls on productivity. In: L. F. Huenneke, Mooney, H. [eds.]. Grassland structure and function: California annual grassland. Dordrecht, The Netherlands: Kluwer Academic Publishers, $p$ 173-199.

MiLchunas, D. G., W. K. Lauenroth, And I. C. BuRke. 1998. Livestock grazing: animal and plant biodiversity of shortgrass steppe and the relationship to ecosystem function. Oikos 83:65-74

Milchunas, D. G., O. E. Sala, and W. K. Lauenroth. 1988. A generalized model of the effects of grazing by large herbivores on grassland community structure. American Naturalist 132:87-106.

Noy-MeIR, I. 1995. Interactive effects of fire and grazing on structure and diversity of Mediterranean grasslands. Journal of Vegetation Science 6:701-710.

NydeggeR, N. C., AND G. W. Smith. 1986. Prey populations in relation to Artemisia vegetation. Proceedings: Symposium on the Biology of Artemisia and Chrysothamnus. 9-13 July 1994; Provo, UT. Intermountain Research Station U.S. Forest Service, p 152-156.

OGden, V. T., AND M. G. Hornocker. 1977. Nesting density and success of prairie falcons in southwestern Idaho. Journal of Wildlife Management 41:1-11.

Owings, D. H. AND M. Borchert. 1975. Correlates of burrow location in beechey ground squirrels. Great Basin Naturalist 35:402-404.

Parsons, A. J., B. Collett, and J. Lewis. 1984. Changes in the structure and physiology of a perennial ryegrass sward when released from continuous stocking management-implication for the use of exclosure cages in continuously stacked swards. Grass and Forage Science 39:1-9.

Pitelka, F. A., P. O. Tomich, And G. W. Treichel. 1955. Ecological relations of jaegers and owls and lemming predators near Barrow, Alaska. Ecological Monographs 25:85-117.

Proulx, M., and A. Mazumder. 1998. Reversal of grazing impact on plant species richness in nutrient-poor vs. nutrient-rich ecosystems. Ecology 79: 2581-2592.

Reynolds, T. D., and C. H. Trost. 1980. The response of native vertebrate populations to crested wheatgrass planting and grazing by sheep. Journal of Range Management 33:122-125.

RickARD, W. H., D. W. URESK, AND J. F. CLINE. 1975. Impact of cattle grazing on three perennial grasses in south-central Washington. Journal of Range Management 28:108-112.

Roundy, B. A., AND G. L. JoRdAn. 1988. Vegetation changes in relation to livestock 
exclusion and root plowing in southeastern Arizona (USA). Southwestern Naturalist 33:425-436.

SAS System [COMPUTER PROgRam]. 2000. Release 8.1. Cary, NC: The SAS Institute, Inc.

Schooley, R. L., P. B. Sharpe, and B. Van Horne. 1996. Can shrub cover increase predation risk for a desert rodent? Canadian Journal of Zoology 74:157-163.

Schuman, G. E., J. D. Reeder, J. T. Manley, R. H. Hart, and W. A. Manley. 1999. Impact of grazing management on the carbon and nitrogen balance of a mixed-grass rangeland. Ecological Applications 9:65-71.

Sharpe, P. B., and B. Van Horne. 1998. Influence of habitat on behaviour of Townsend's ground squirrels (Spermophilus townsendii). Journal of Mammalogy 79:906-918.

SteENHOF, K., AND M. N. KocheRT. 1988. Dietary responses of three raptor species to changing prey densities in a natural environment. Journal of Animal Ecology 57:37-48.

Stohlgren, T. J., L. D. Schell, and H. B. Vanden. 1999. How grazing and soil quality affect native and exotic plant diversity in Rocky Mountain grasslands. Ecological Applications 9:45-64.

StoreR, T. I. 1942. Control of injurious rodents in California. Davis, CA: California Agricultural Extension Service Circular. $66 \mathrm{p}$.

SvenDSEN, G. E. 1976. Structure and location of burrows of yellow-bellied marmot. Southwestern Naturalist 20:487-494.

Swaisgood, R. R., D. H. Owings, And M. P. Rowe. 1999. Conflict and assessment in a predator-prey system: ground squirrels versus rattlesnakes. Animal Behavior 57:1033-1044.

SzARO, R. C., AND C. P. PASE. 1983. Short-term changes in a cottonwood-ash-willow association on a grazed and an ungrazed portion of Little Ash Creek in central Arizona (USA). Journal of Range Management 36:382-384.

Van Horne, B., R. L. Schooley, S. T. Knick, G. S. Olson, and K. P. Burnham. 1997. Use of burrow entrances to indicate densities of Townsend's ground squirrels. Journal of Wildlife Management 61:92-101.

WHITE, K. L. 1967. Native bunchgrass (Stipa pulchra) on Hastings Reservation, California. Ecology 48:949-955. 